\title{
PERANCANGAN BASIS DATA IMPROVEMENT DASHBOARD APPLICATION: STUDI KASUS PADA PADANG KARUNIA GROUP
}

\author{
Ayuliana; Nailur Rahma; Titis Aulia; Ratri Permatasari \\ Computer Science Department, School of Computer Science, Binus University \\ Jl. K.H. Syahdan No. 9, Palmerah, Jakarta Barat 11480 \\ ayuliana_st@binus.ac.id
}

\begin{abstract}
Padang Karunia Group received a lot of inputs from its employees for improvement collected manually by an administrator. The more input from employees, the more difficult to be collected manually. Therefore Padang Karunia Group took the initiative to create an intranet application to save the inputs in a database. Based on this problem, a research is done to develop database applications in the form of dashboard to collect criticisms and suggestions of employees over the web. This application is expected to assist and facilitate the management of the company, especially in the gathering criticism and suggestions from employees who are then evaluated for company improvement. We uses the database design method based on database application lifecycle, including requirements collection and analysis, conceptual database design, logical database design, DBMS selection, physical database design, and implementation. The results achieved are a database design and a web-based dashboard application that collects criticisms and suggestions. The advantage of using this application is that the company can easily accept criticism and suggestions from employees, simplify storage and data management criticism and suggestions, create reports, and reduce the cost of data collection and the process that was previously done manually. Through the database created, the data management of criticisms and suggestions of employees can be done better.
\end{abstract}

Keywords: analysis, design, application, dashboard

\begin{abstract}
ABSTRAK
Padang Karunia Group banyak sekali menerima masukan dari karyawan untuk perbaikan perusahaan yang dikumpulkan secara manual oleh administrator. Semakin banyak masukan dari karyawan, semakin sulit mengumpulkannya secara manual untuk kemudian dikelompokan dan dievaluasi. Oleh karena itu Padang Karunia Group berinisiatif untuk membuat sebuah aplikasi intranet untuk menginput masukan-masukan dari para karyawan dan menampungnya dalam sebuah basis data. Berdasarkan masalah tersebut, penelitian dilakukan untuk mengembangkan aplikasi database untuk Padang Karunia Group berupa dashboard untuk mengumpulkan kritik dan saran karyawan melalui web. Aplikasi ini diharapkan dapat membantu dan memudahkan perusahaan khususnya pihak manajemen dalam mengumpulkan kritik dan saran dari para karyawan yang kemudian di evaluasi untuk pengembangan perusahaan. Metode yang akan digunakan adalah metode perancangan basis data berdasarkan pada database application lifecycle yang meliputi requirement collection and analysis, conceptual database design, logical database design, DBMS selection, physical database design, dan implementation. Hasil yang dicapai berupa rancangan basis data dan sebuah aplikasi dashboard berbasis web yang dapat mengumpulkan kritik dan saran. Keuntungannya adalah perusahaan dapat dengan mudah menerima kritik dan saran dari karyawan, mempermudah penyimpanan dan pengelolaan data kritik dan saran, membuatan laporan, dan mengurangi proses dan biaya pengumpulan data yang sebelumnya dilakukan secara manual. Melalui database yang dibuat, pengelolaan informasi data kritik dan saran maupun data karyawan menjadi lebih baik,
\end{abstract}

Kata kunci: analisis, perancangan, aplikasi, dashboard 


\section{PENDAHULUAN}

Teknologi informasi dapat digunakan untuk menampung data secara masal, sehingga dapat membantu perusahaan yang menerapkannya mendapatkan informasi dalam jumlah besar dan dalam waktu yang singkat. Data dikumpulkan dalam sebuah basis data. Basis data menurut Connoly dan Begg (2010) adalah tempat pengumpulan data yang sangat besar digunakan secara bersama-sama oleh berbagai departement dan pengguna. Deskripsi dari data tersebut dirancang untuk memenuhi kebutuhan informasi dari sebuah organisasi.

Padang Karunia Group adalah sebuah perusahaan yang bergerak dalam bidang Coal Mining, Trading, Contractor dan Infrastructrure. Perusahaan ini merupakan kelompok usaha dalam TRIPUTRA GROUP yang sudah mengembangkan bisnisnya sejak tahun 2002 dan sudah berkembang dengan pesat hingga saat ini. Jumlah karyawan yang di miliki perusahaan sudah cukup banyak dan masing-masing individu mempunyai dan sering mengajukan ide-ide yang sangat bagus untuk perbaikan perusahaan.

Pengembangan maupun perbaikan perusahaan tidak terlepas dari peran Quality Circle, yaitu sekelompok kecil yang terdiri dari enam sampai 12 karyawan yang melakukan pekerjaan serupa secara sukarela bertemu secara reguler untuk mengidentifikasi perbaikan dan pengendalian mutu (Prasanna dan Desai, 2011). Persepsi Quality Circle saat ini adalah appropriateness for use dan the tactic implemented adalah untuk mencegah ketidaksempurnaan dalam pelayanan daripada verifikasi dan eliminasi. Oleh karena itu sikap karyawan mempengaruhi kualitas. Hal ini mendorong partisipasi karyawan serta mempromosikan kerja sama tim sehingga memotivasi orang untuk berkontribusi terhadap efektivitas organisasi melalui proses kelompok (Gaikwad dan Gaikwad, 2009).

Padang Karunia Group untuk menampung ide-ide karyawan tersebut secara manual yang dikumpulkan oleh seorang administrator. Akan tetapi perusahaan menyadari bahwa semakin banyak ide-ide dari karyawan, akan semakin sulit mengumpulkannya satu per satu secara manual, untuk kemudian dikelompokan dan dievaluasi. Oleh karena itu perusahaan berinisiatif untuk membuat sebuah aplikasi intranet untuk menginput masukan-masukan dari para karyawan dan menampungnya dalam sebuah basis data. Aplikasi ini di sebut dengan improvement dashboard application (yang selanjutnya akan kami tulis IDA) agar ide-ide bagus dari para karyawan dapat terkumpul dengan baik, dievaluasi secara akurat sehingga perusahaan dapat lebih maju dan berkembang lagi.

Berhubungan dengan masalah di atas, penelitian ini ditujukan untuk membuat rancangan sistem basis data untuk IDA, yang meliputi: (1) form untuk menyampaikan masukan/pengajuan usulan yang berkaitan dengan berusahaan. Usulan ini diberikan oleh karyawan golongan supervisor ke bawah; (2) perbandingan data, menampilkan tabel, dan grafik yang berisi kumpulan usulan perbaikan dari tahun ke tahun sehingga dapat dijadikan bahan perbandingan dan pertimbangan tim manajemen; (3) memberikan sejumlah test untuk karyawan untuk mengetahui tingkat pemahaman karyawan mengenai suggestion system (SS), quality control circle (QCC), dan quality control procedure (QCP).

Dengan adanya IDA ini, diharapkan Padang Karunia Group dapat melakukan perbaikan untuk perusahaannya sehingga perusahaan ini bisa lebih baik lagi kedepannya.

\section{METODE}

Penelitian ini berdasarkan pada kenyataan bahwa semakin berkembangnya Padang Karunia 
Group seiring dengan semakin bertambahnya jumlah karyawan, sehingga semakin banyak kritik dan saran yang membangun yang disampaikan oleh karyawan. Oleh karena itu perusahaan memerlukan IDA (improvement dashboard application) untuk mempermudah pengumpulan kritik dan saran para karyawan, yang kemudian di evaluasi.

Data yang digunakan adalah data primer, yang diperoleh dengan melakukan wawancara kepada pihak-pihak terkait dalam proses pengumpulan data kritik dan saran, sehingga dapat diketahui proses apa saja yang terjadi dan data apa saja yang dibutuhkan untuk mendukung proses tersebut, juga data atau informasi apa saja yang dihasilkan/dibutuhkan. Observasi dilapangan dilakukan untuk mengamati dan memeriksa kesesuaian hasil wawancara dengan fakta dilapangan. Pemeriksaan dokumen-dokumen terkait yang timbul maupun yang diperlukan dalam terjadinya proses juga dilakukan untuk memperkuat analisis mengenai sistem yang sedang berjalan dan kebutuhan user pada sistem yang baru.

Data kualitatif/data sekunder didapat dari studi kepustakaan mengenai sistem basis data, dashboard application, dan segala hal yang berhubungan dengan topik pembahasan yang keseluruhannya bersifat teoritis untuk menunjang pembahasan permasalahan mengenai pemanfaatan sistem basis data untuk mendukung IDA.

Pengolahan dan analisis data, dilakukan sesuai dengan batasan penelitian dengan tujuan dapat menjawab permasalahan. Setelah data diolah, diharapkan didapat suatu aplikasi yang dapat membantu perusahaan khususnya tim manajemen dalam mencapai tujuannya.

\section{HASIL DAN PEMBAHASAN}

\section{Survei Sistem Berjalan}

\section{Prosedur Instruksi Kerja SS (Sugestion System)}

Karyawan membuat suggestion system (SS) dengan form standar SS. SS adalah media yang melibatkan karyawan untuk upaya perbaikan mutu melalui saran-saran perbaikan yang umumnya dilakukan perorangan. SS kemudian diajukan kepada atasan dengan melampirkan data pendukung. Selanjutnya atasan akan memeriksa dan menentukan apakah SS tersebut layak untuk diajukan ke komite atau perlu diperbaiki kembali.

Bila disetujui, form SS ditandatangani oleh atasan dan diberikan kembali kepada karyawan pembuat SS. Form SS yang sudah ditandatangani kemudian disimpan oleh karyawan sebagai arsip, sedangkan softcopy dan data-data pendukung dikirimkan via email kepada komite improvement.

Komite menerima email SS dari karyawan kemudian memasukkan data tersebut ke intranet improvement. Komite akan melakukan penilaian SS diakhir bulan melalui wawancara dengan karyawan pembuat SS. Hasil penilaian direkap dan diumumkan kepada seluruh karyawan setiap awal bulan berikutnya.

Proses registrasi SS ini dirangkum pada Gambar 1 di bawah ini. Prosedur Instruksi Kerja QCC/QCP (Quality Control Circle/ Quality Control Procedure)

Anggota gugus mengerjakan langkah 1 dari QCC/QCP. Atasan memonitoring jalannya tahapan QCC/QCP dan anggota gugus mengajukan untuk melakukan Pre Test ke komite. 
Komite mempersiapkan soal Pre Test dan Post Test dan anggota gugus segera mengerjakan Pre Test terlebih dahulu. Selanjutnya komite melakukan penilaian pre test. Komite menginformasikan hasil pre test kepada anggota gugus dan anggota gugus menerima hasil nilai pre test.

Anggota gugus melanjutkan tahapan QCC/QCP dan di monitoring perkembangan langkah QCC/QCP oleh komite. Hasil penilaian direkap dan diumumkan kepada seluruh karyawan setiap awal bulan berikutnya.

Anggota gugus mengajukan untuk melakukan post test ke komite. Selanjutnya komite melakukan penilaian post test. Komite menginformasikan hasil post test kepada anggota gugus dan anggota gugus menerima hasil nilai post test. Anggota gugus menyelesaikan tahapan dan dokumentasi QCC/QCP, lalu di kumpulkan ke komite.

Proses registrasi dan monitoring QCC/QCP dirangkum pada Gambar 2 di bawah ini.

\section{System Boundaries}

System boundaries merupakan batasan dari sistem yang akan dibuat pada sistem database IDA Padang Karunia Group yang digambarkan di bawah ini (Gambar 3):

\section{Permasalahan yang Dihadapi}

Berdasarkan pada hasil survei yang dilakukan pada Padang Karunia Group terhadap kebutuhan sistem yang sedang berjalan saat ini, ditemukan masalah-masalah sebagai berikut: (1) kemungkinan terjadinya kehilangan data, kesulitan dalam pencarian data dan duplikasi data ide-ide dari karyawan karena dikumpulkan satu per satu secara manual; (2) waktu proses pengumpulan data yang dibutuhkan cenderung meningkat seiring dengan bertambahnya jumlah karyawan dan jumlah ide yang akan diajukan; (3) data setiap bagian belum terintegrasi sehingga dapat menyebabkan ketidakkonsistenan data pada tempat penyimpanan data; (4) user memiliki kesulitan dalam menyimpan data dan menampilkan data yang dibutuhkan. Juga pada saat mengakses kebutuhan informasi, sehingga dibutuhkan suatu mekanisme yang menjaga keamanan, integritas dan konsistensi data ketika data yang dibutuhkan tidak sesuai dan berubah-ubah.

\section{Rencana Pemecahan Masalah}

Berdasarkan hasil analisis terhadap permasalahan yang dihadapi oleh Padang Karunia Group saat ini, dibutuhkan suatu aplikasi basis data yang terintegrasi dengan baik untuk menggantikan sistem konvensional. Diharapkan dengan aplikasi ini, akan mempermudah perusahaan dalam mengelola data, mencari data, melakukan perbandingan data, perhitungan dengan beberapa data, dan meningkatkan keamanan data.

Rancangan sistem yang diusulkan digambarkan dengan diagram konteks (Gambar 4) dan diagram nol (Gambar 5) yang menjelaskan proses-proses dalam prosedur instruksi kerja SS dan prosedur instruksi kerjaQCC/QCP, berikut dengan perancangan basis data konseptual (Gambar 6), logikal (Gambar 7) sesuai dengan tahapan siklus hidup aplikasi basis data (Connolly dan Begg, 2005).

Dengan melakukan langkah-langkah seperti: menghilangkan tipe relasi many to many, multi valued atribut, menentukan entitas kuat dan lemah, dan memvalidasi dengan normalisasi, diperoleh ERD sebagai berikut (Gambar 7). Rancangan struktur menu ditampilkan sebagai berikut (Gambar 8 9). 


\section{Proses registrasi SS}

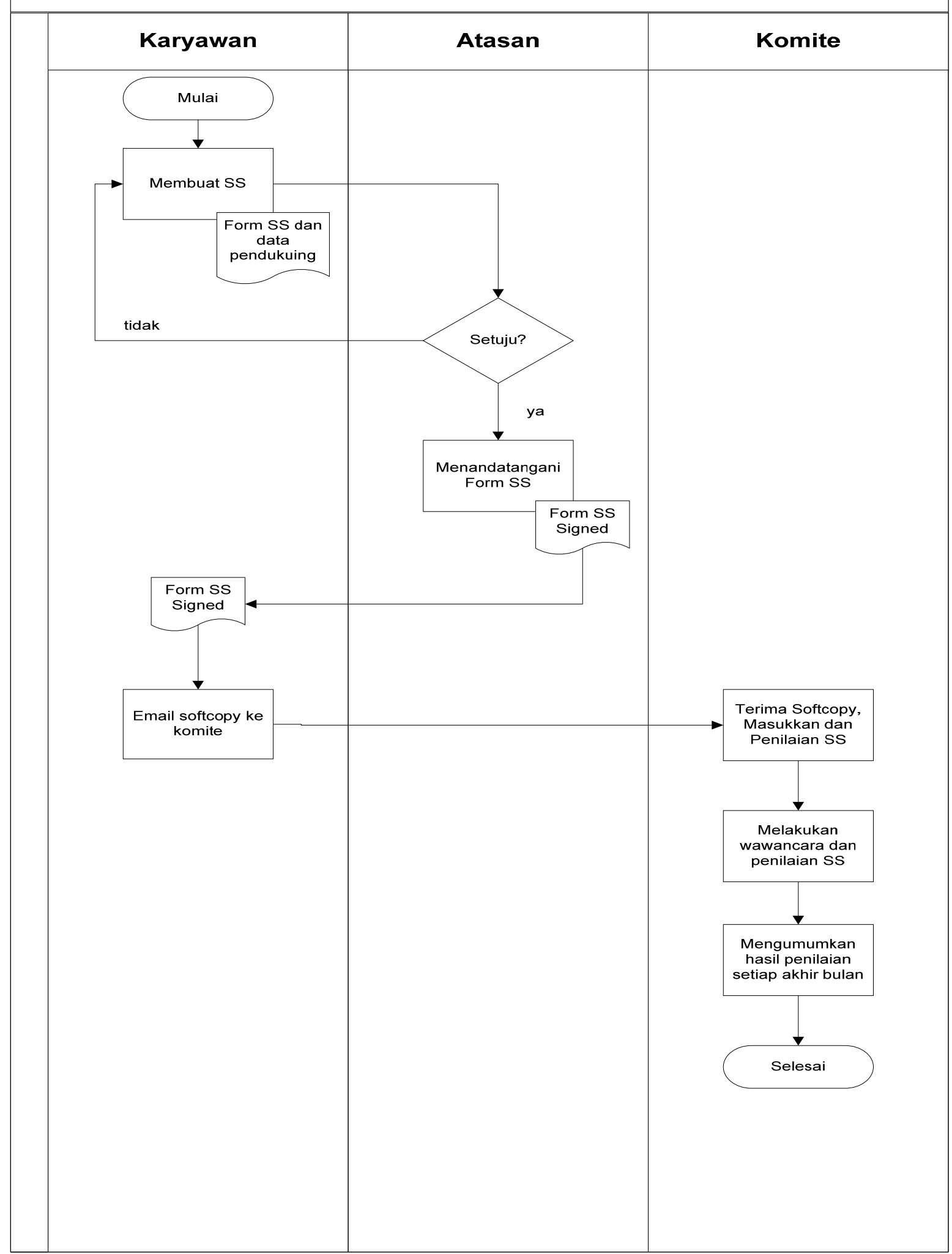

Gambar 1 Flowchart SS 


\section{Proses registrasi dan monitoring QCC/QCP}

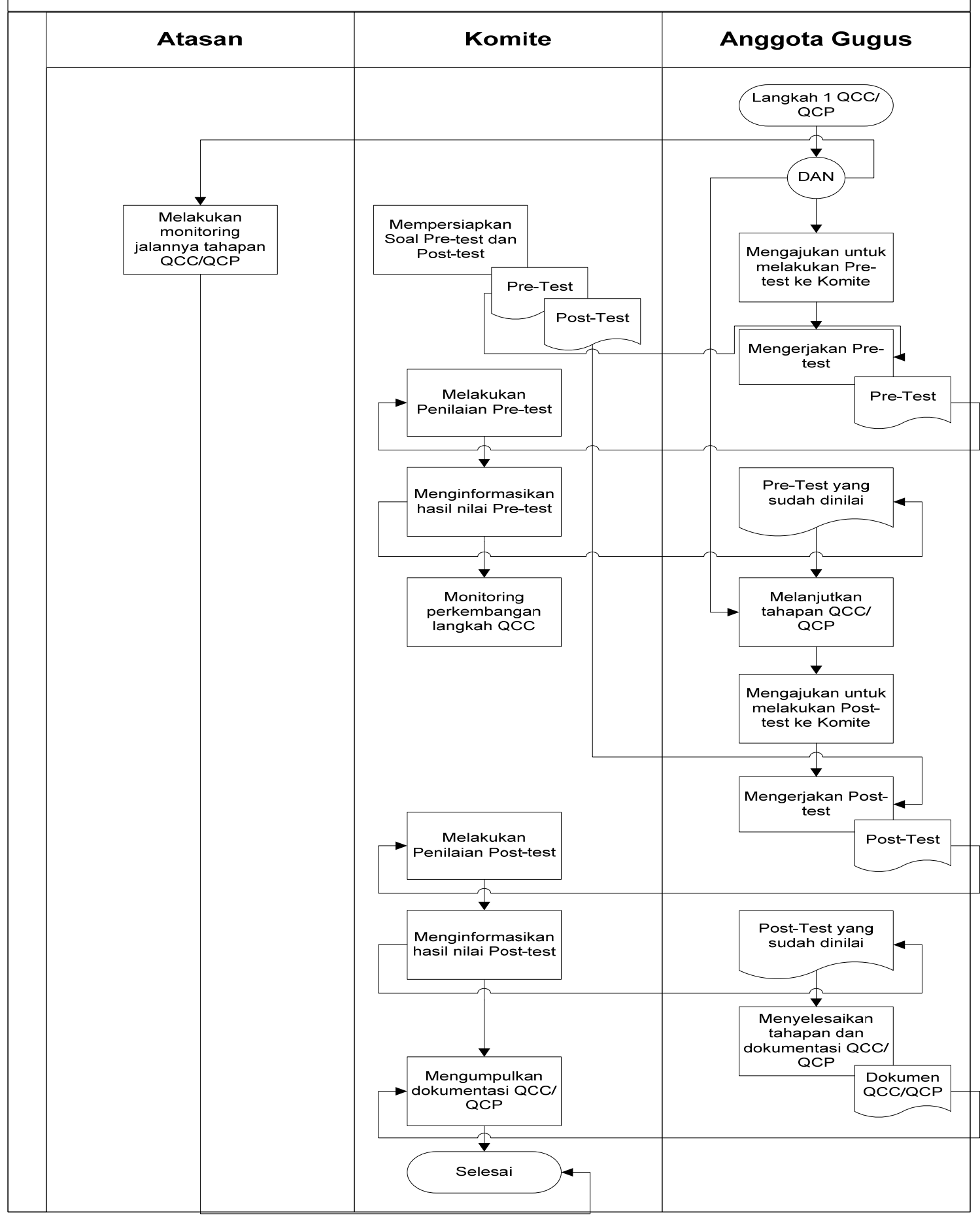

Gambar 2 Flowchart QCC/QCP 


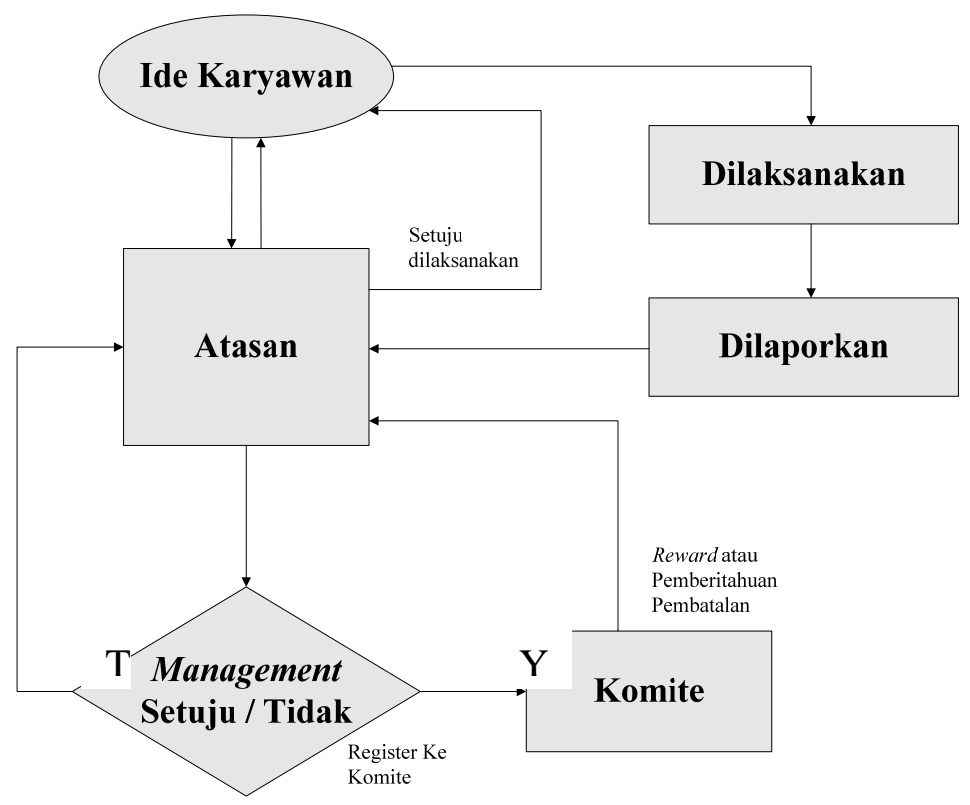

Gambar 3 System boundaries

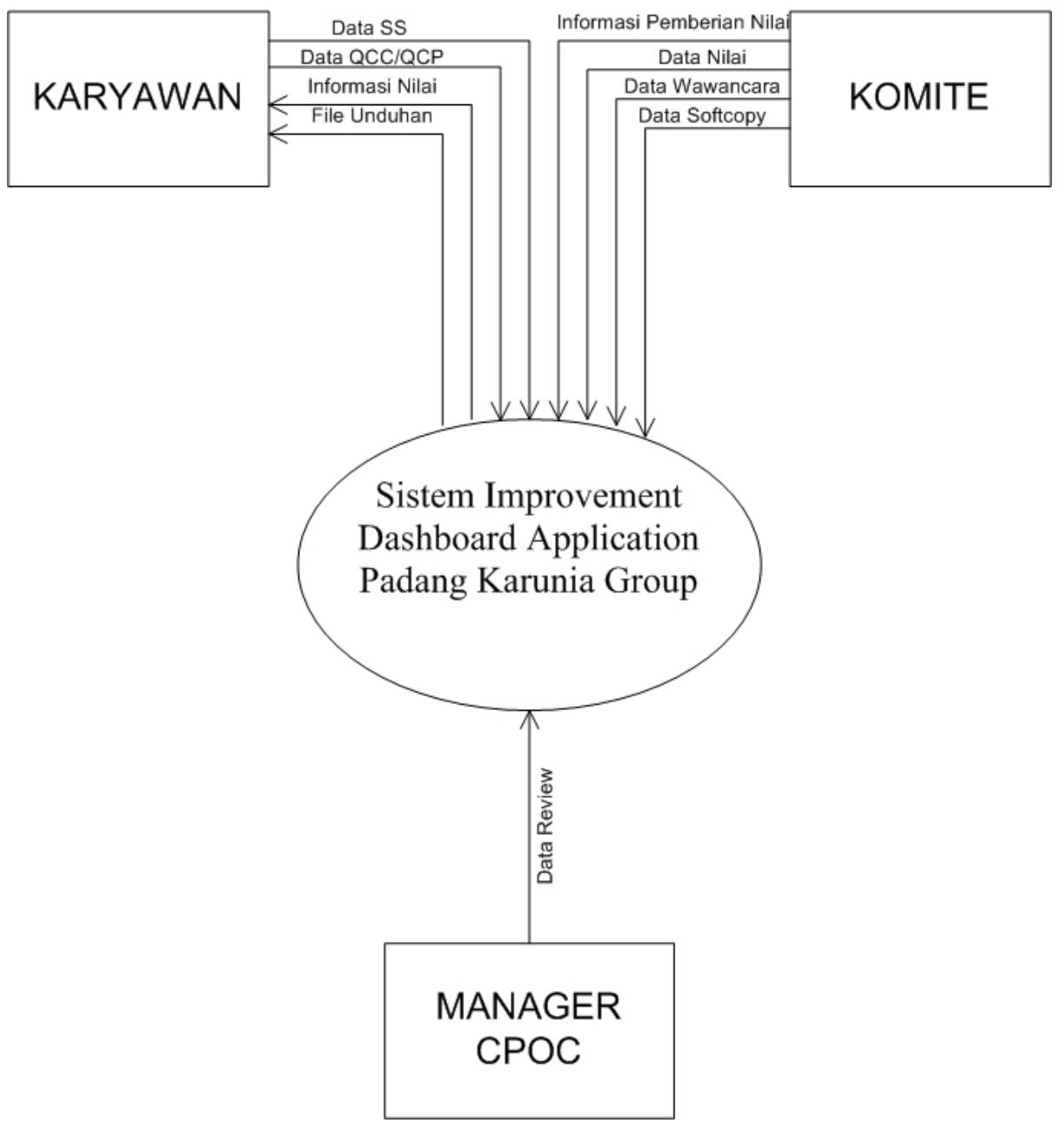

Gambar 4 Diagram konteks 


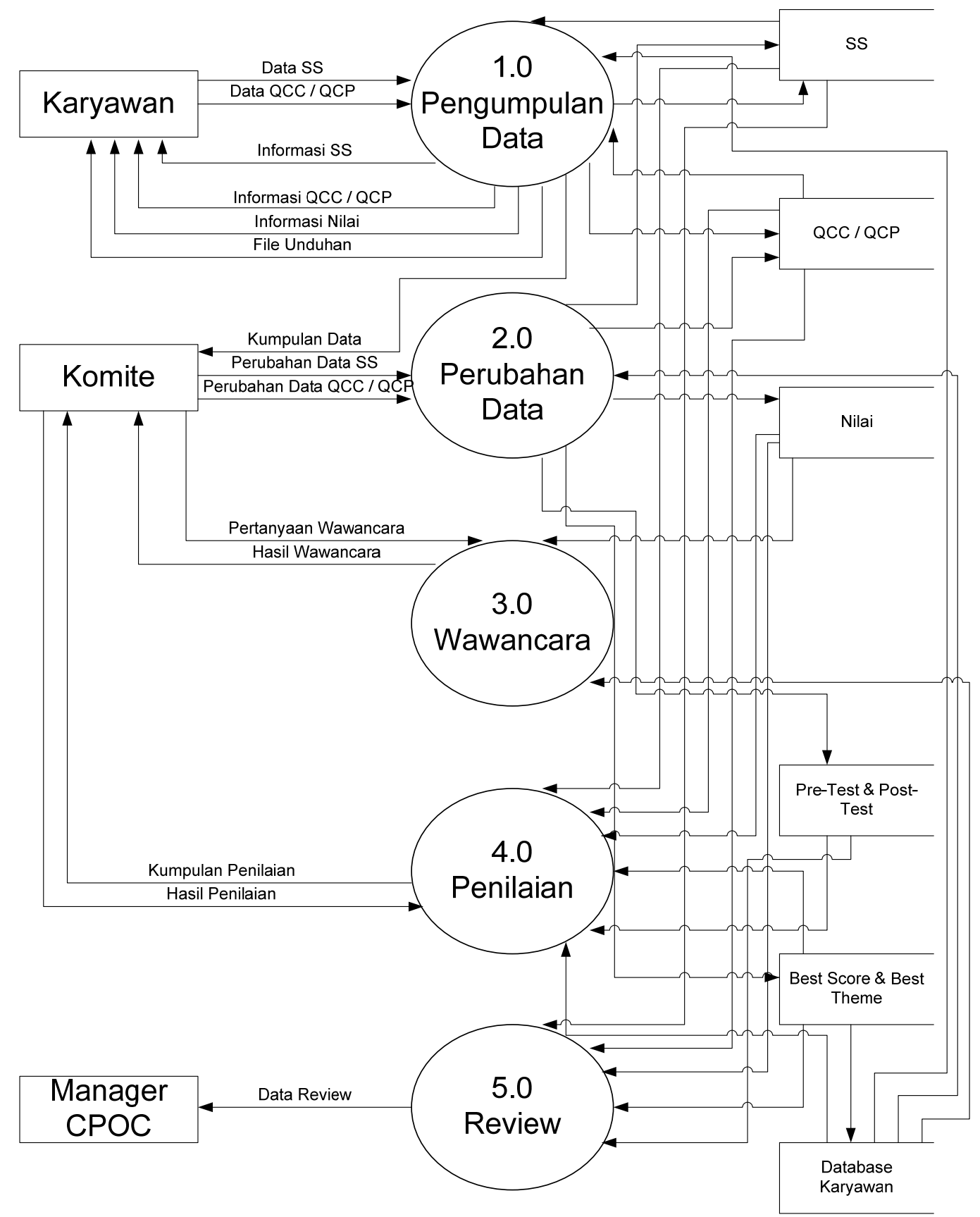

Gambar 5 Diagram nol 

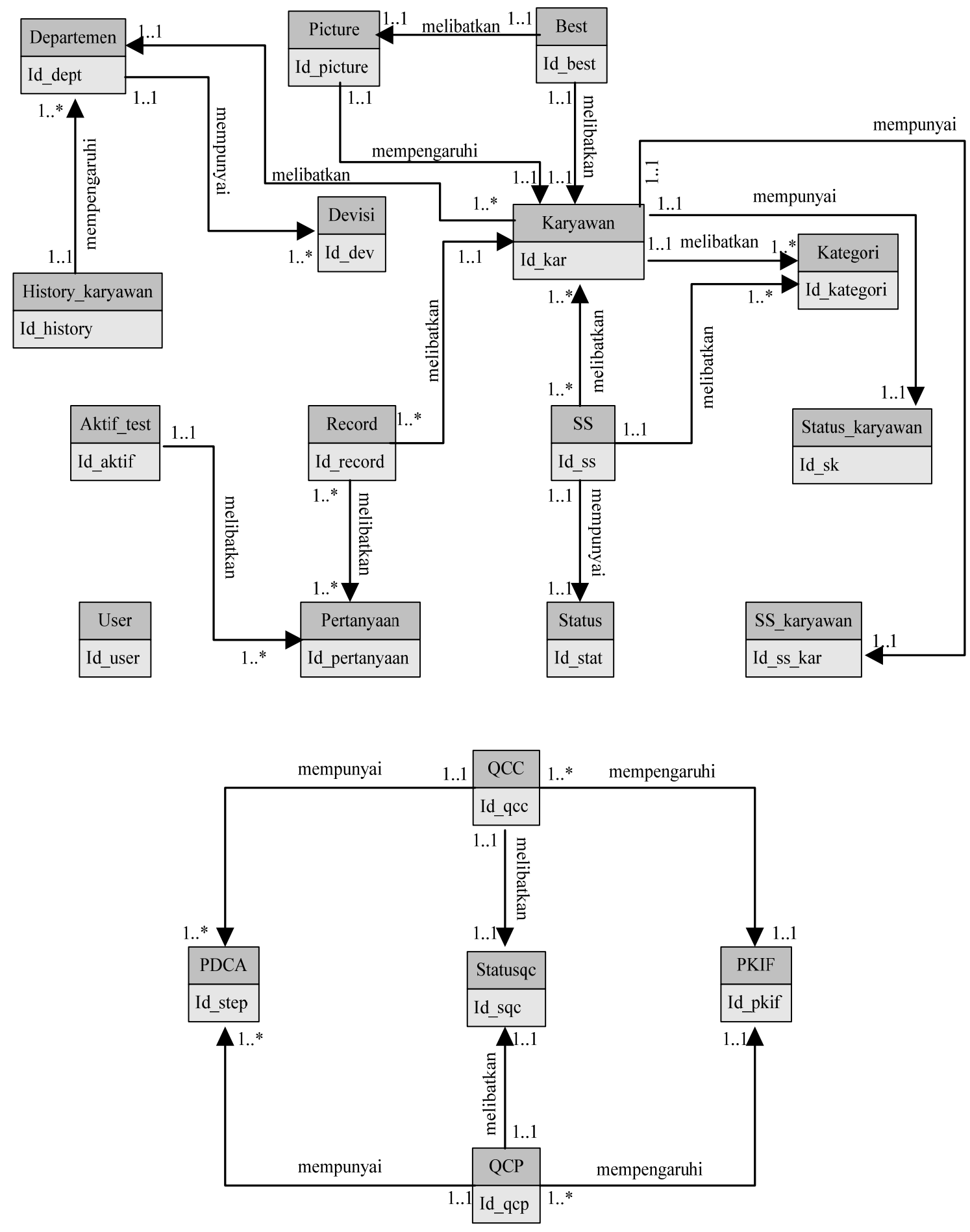

Gambar 6 ERD konseptual dengan primary key 


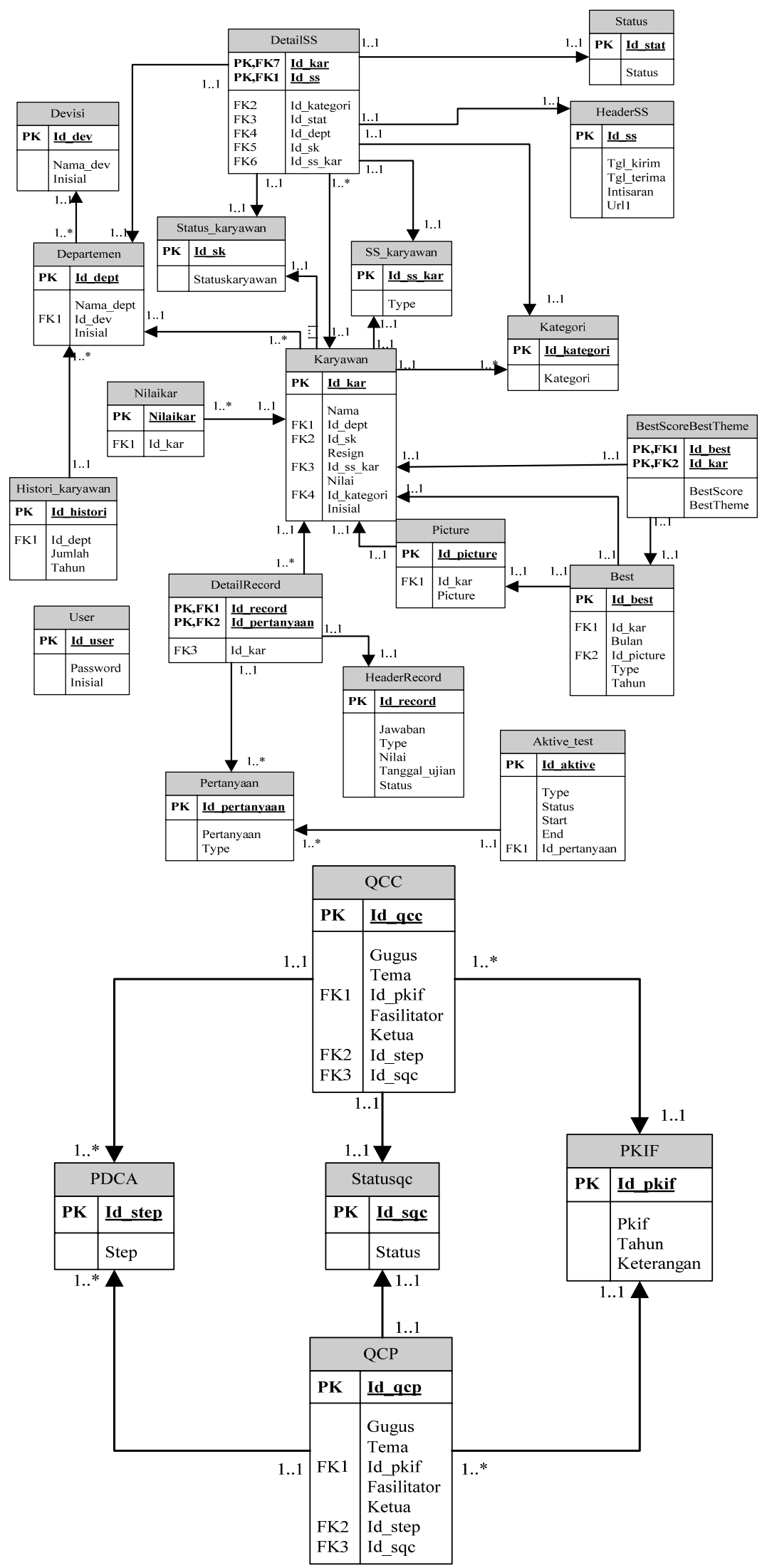

Gambar 7 ERD model global 


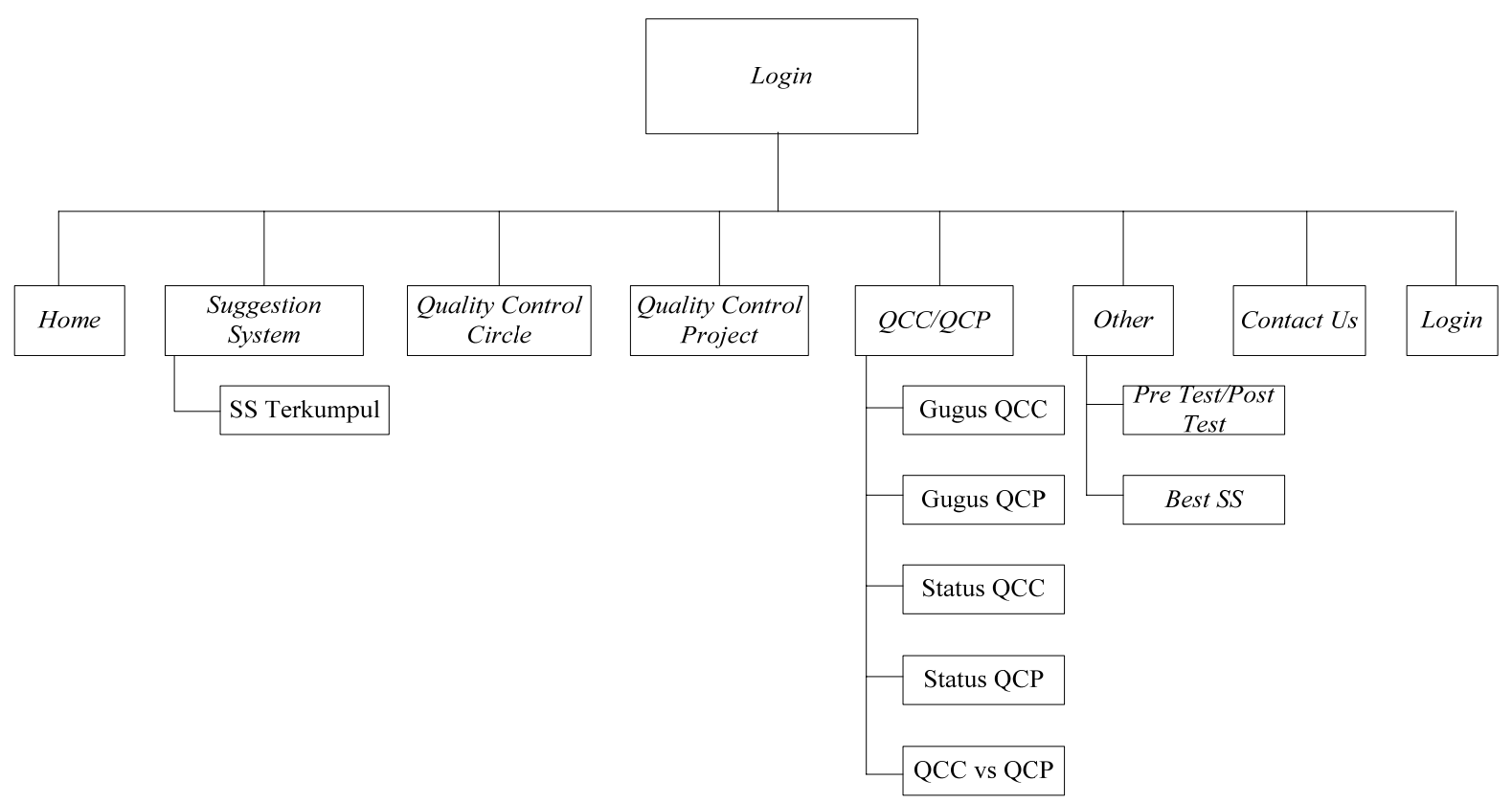

Gambar 8 Perancangan struktur menu karyawan

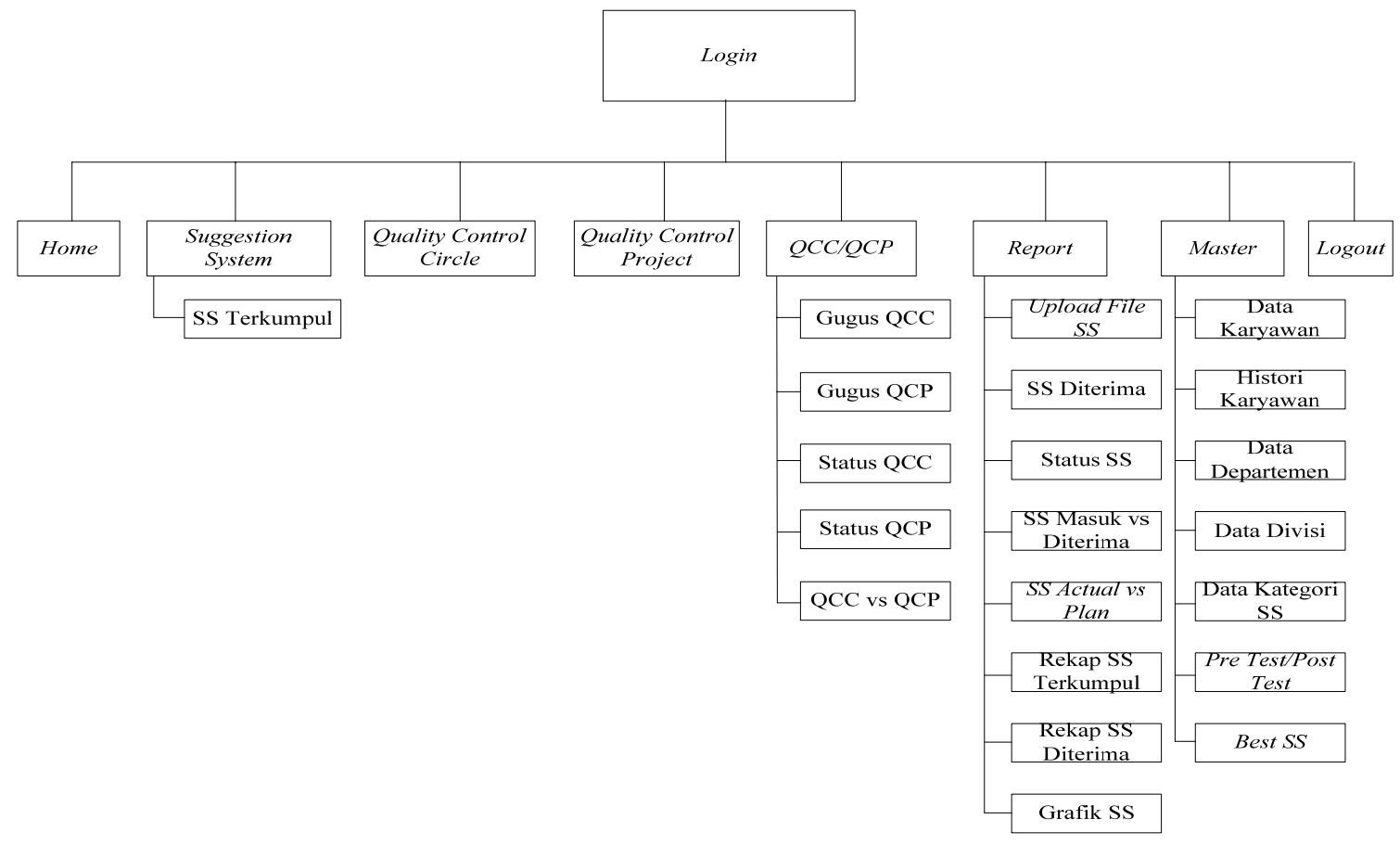

Gambar 9 Perancangan struktur menu admin

\section{Tampilan Layar IDA}

Setelah berhasil login, tampilan awal adalah halaman Home adalah seperti Gambar 10. Pada halaman ini, terdapat menu-menu yang dapat dipilih dengan cara meng-klik menu yang diinginkan. 


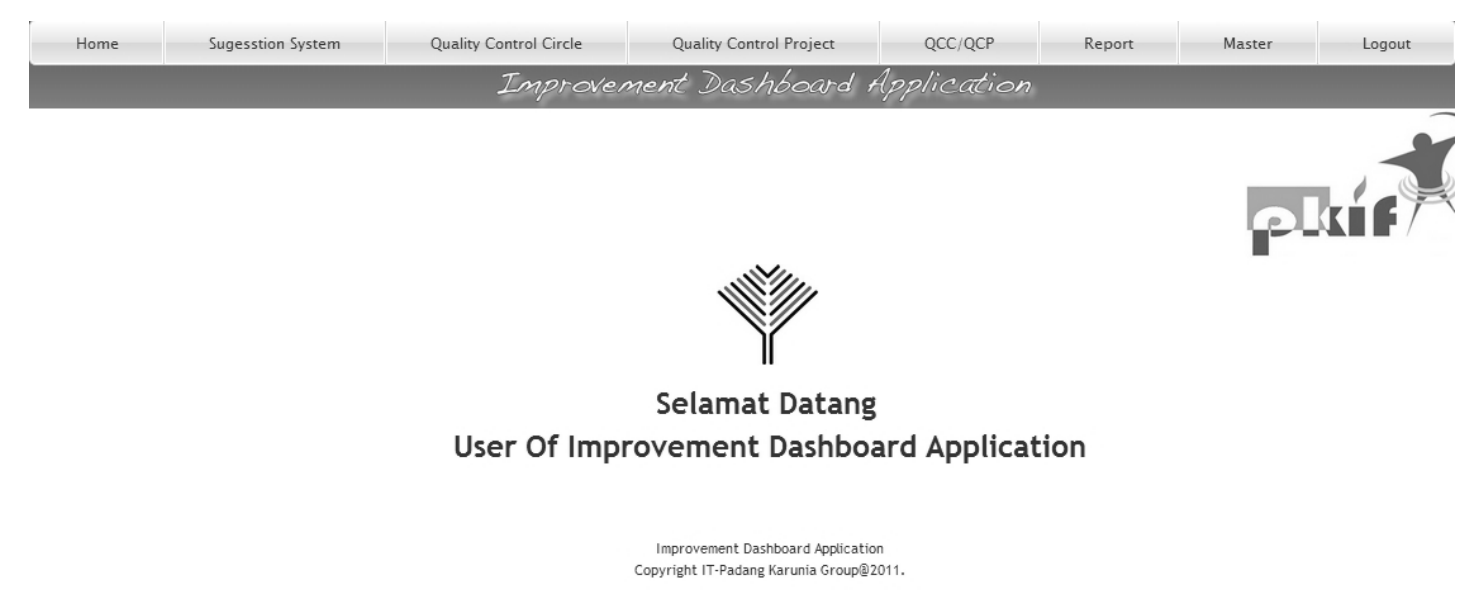

Gambar 10 Tampilan layar Home

Gambar 11 di bawah ini muncul apabila menu Suggestion System di klik. Pada halaman ini terdapat daftar nama-nama karyawan yang telah mengumpulkan SS beserta informasi kategori, inti saran dan status SS yang sudah dikumpulkan. Terdapat juga field yang berfungsi untuk melakukan pencarian berdasarkan semua attribute. Selain itu halaman ini juga di lengkapi dengan tombol tombol add, detail, edit dan delete. Tombol add berfungsi untuk menampilkan form yang harus diisi untuk menambah list SS Terkumpul. Tombol detail berfungsi untuk menampilkan detail data yang diisi oleh karyawan. Tombol edit berfungsi untuk melakukan perubahan pada list SS Terkumpul.

\begin{tabular}{|c|c|c|c|c|c|c|c|c|}
\hline \multicolumn{9}{|c|}{ Improvement Dashboard Application } \\
\hline \multicolumn{9}{|c|}{ Data SS Terkumpul All } \\
\hline : Pilih Karyawan :- & - : Plilih Kategori:- & - Inti Saran: & \multicolumn{2}{|l|}{$\because$ Pilih Status $:-\operatorname{Jan} \sim 2013 \sim$ Search } & \multirow[b]{2}{*}{ File SS } & & & \\
\hline No. & Karyawan & Kategori & Inti Saran & Status & & \multicolumn{2}{|c|}{(} & 图 \\
\hline 1 & Desty F. Handayani & GA & $\begin{array}{l}\text { WI Pemesanan Tiket Pesawat \& Voucher Hotel dengan Sistem } \\
\text { Online }\end{array}$ & SS Diterima & File SS & Q & 2 & $\mathbf{x}$ \\
\hline 2 & Anastasia Putri Hadiprojo & $\mathrm{HR}$ & Pembuatan report man power bulanan & SS Diterima & File SS & Q & $?$ & $\mathbf{x}$ \\
\hline 3 & Anastasia Putri Hadiprojo & HR & Penggunaan Form Usulan Pervbahan Struktur Organisasi & SS Diterima & File SS & $\mathrm{Q}_{\mathbf{S}}$ & $?$ & $\mathbf{x}$ \\
\hline 4 & Suratmo & 5R & Memberi papan nama perusahaan dipintu gerbang utama & SS Diterima & File SS & Q & ? & $\mathbf{x}$ \\
\hline 5 & Suratmo & GA & Memasang karpet jalan setelah mengambil wudlu & SS Diterima & File SS & $\mathrm{O}_{8}$ & $?$ & $\mathbf{x}$ \\
\hline 6 & Suratmo & $5 \mathrm{R}$ & Memberi tempat pelatan kotor bekas makan & SS Diterima & File SS & Q & $?$ & $\mathbf{x}$ \\
\hline 7 & Suratmo & GA & PENGADAAN RAK SEPATU DI AREA MUSHOLA & SS Diterima & File SS & Q & ? & $\mathbf{x}$ \\
\hline 8 & Anastasia Putri Hadiprojo & $\mathrm{HR}$ & $\begin{array}{l}\text { Penggunaan distribusi normal dalam proses penilaian kineja } \\
\text { sebagai cerminan }\end{array}$ & Ss Diterima & File SS & Q & $?$ & $\mathbf{x}$ \\
\hline 9 & Nova Anggraini & $\begin{array}{l}\text { ORMCHECK } \\
\text { SHEET/LIST }\end{array}$ & Pembuatan list atas rental yang digunakan PT. ABA & SS Diterima & File SS & $\mathrm{O}_{8}$ & $?$ & $x$ \\
\hline 10 & Suratmo & $\mathrm{GA}$ & 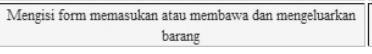 & SS Diterima & File SS & $Q$ & $?$ & $x$ \\
\hline
\end{tabular}

Gambar 11 Tampilan layar SS terkumpul

Apabila menu Gugus QCC di klik akan tampil halaman Gugus QCC seperti Gambar 12 di bawah ini. Pada halaman ini terdapat daftar nama-nama gugus yang sudah mengumpulkan QCC beserta informasi tema, ketua, fasilitator dan tahun QCC yang telah di kumpulkan. Terdapat juga field yang berfungsi untuk melakukan pencarian berdasarkan nama gugus dan tema. Selain itu halaman ini juga di lengkapi dengan tombol tombol add, detail, edit dan delete. 


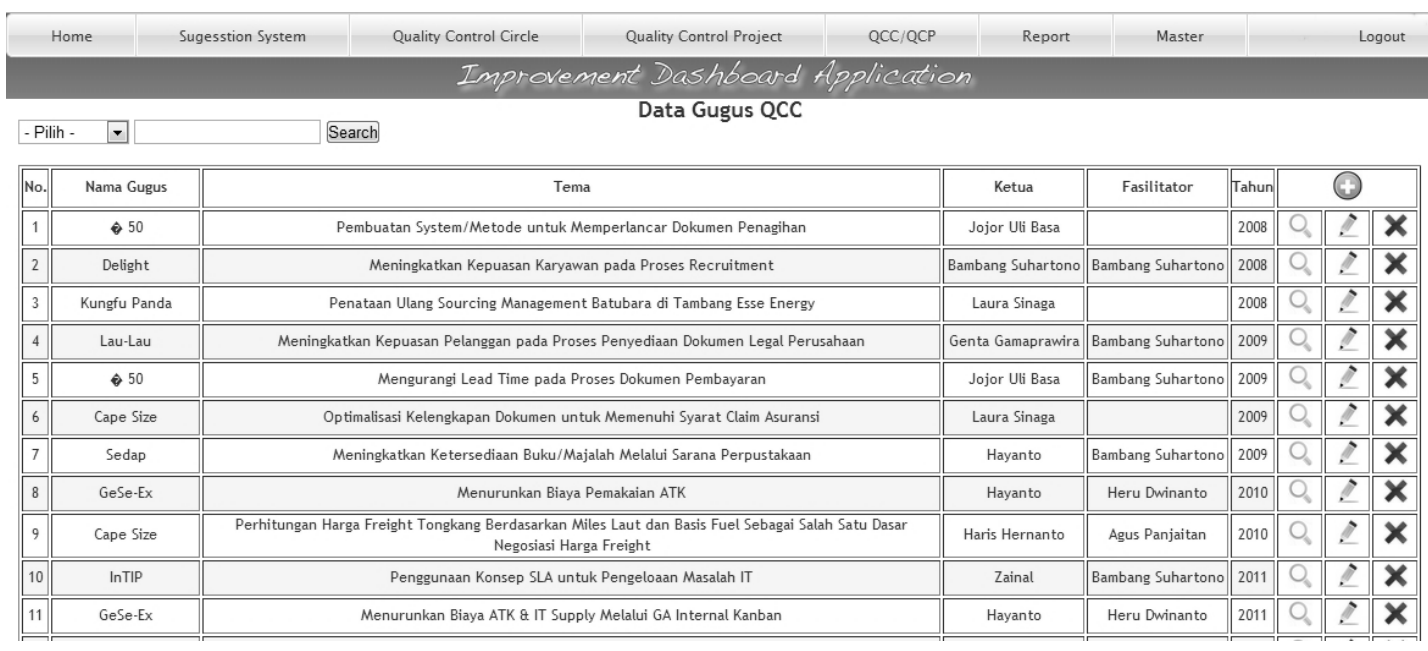

Gambar 12 Tampilan layar Gugus QCC

Apabila menu Pre Test/Post Test diklik, akan tampil halaman Pre Test/Post Test seperti gambar 13. Pada halaman ini terdapat dua sub menu yaitu test yang sedang aktif dan record.

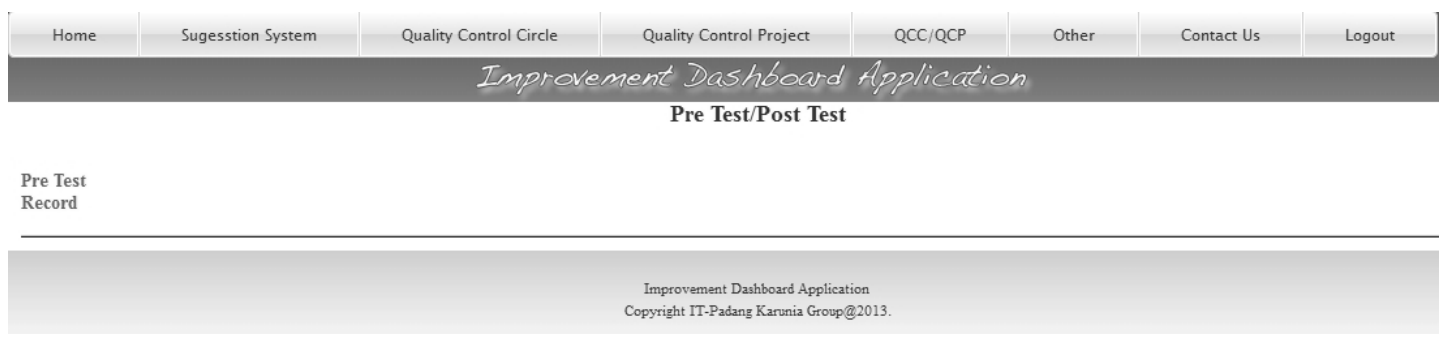

Gambar 13 Halaman Pre Test/Post Test

Jika submenu record diklik pada halaman Pre Test/Post Test, akan tampil daftar record seperti Gambar 14. Halaman ini akan menampilkan nama karyawan yang sedang login. Selain itu juga menampilkan list tipe pertanyaan, pertanyaan, jawaban, tanggal dan nilai yang telah di isi oleh karyawan tersebut.

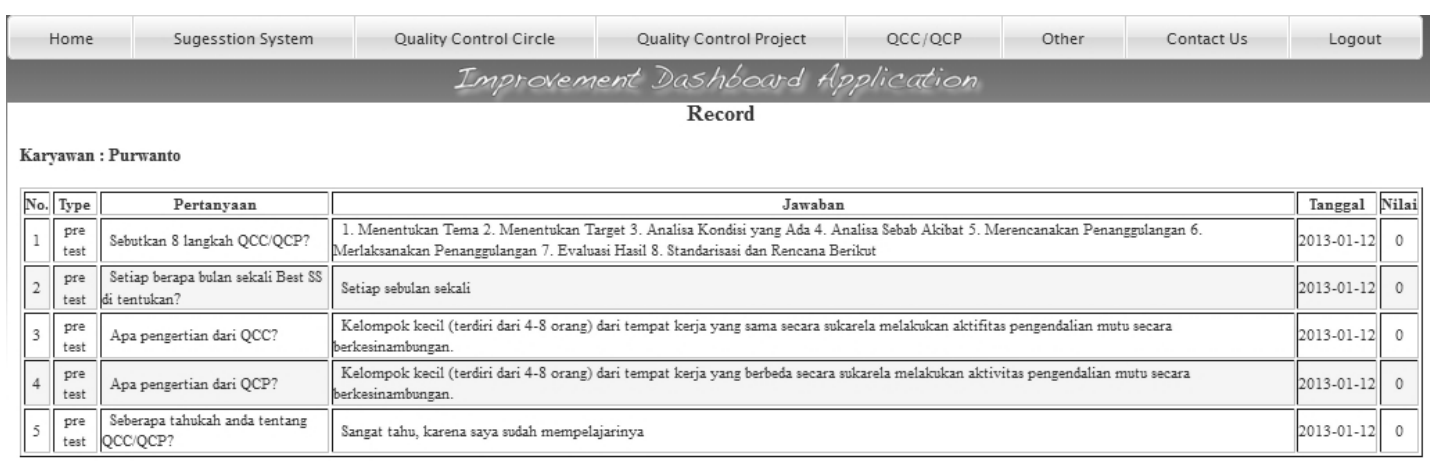

Improvement Dashbourd Application
Copyight TT-Pdang Karunia GrovpQ2013,

Gambar 14 Halaman Record Pre Test/Post Test 
Pada halaman ini terdapat dua nama karyawan yang mendapatkan gelar best score dan best theme (Gambar 15) pada setiap bulannya. Terdapat juga field yang berfungsi untuk melakukan pencarian berdasarkan bulan dan tahun.

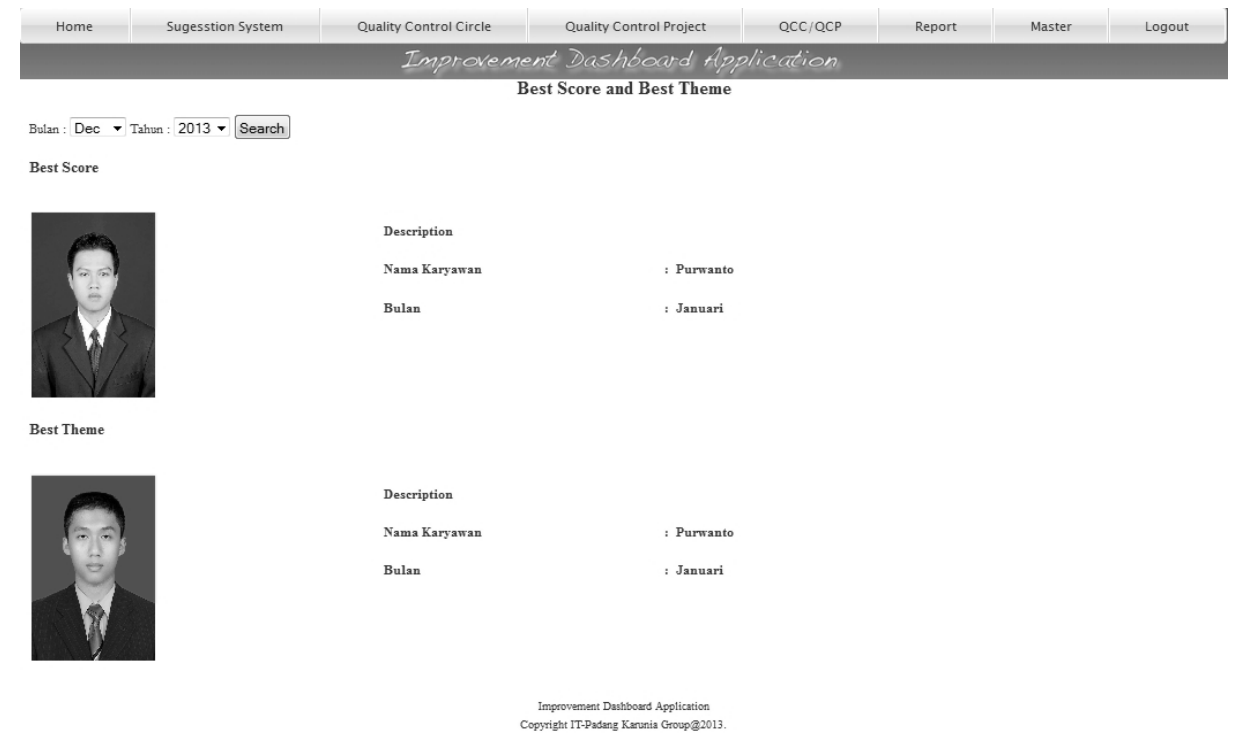

Gambar 15 Halaman Record Best SS

Gambar 16 di bawah ini menampilkan grafik jumlah QCC dan juga tabel keterangan data gugus QCC per tahun. Terdapat juga tombol yang berfungsi untuk melihat data secara detail.

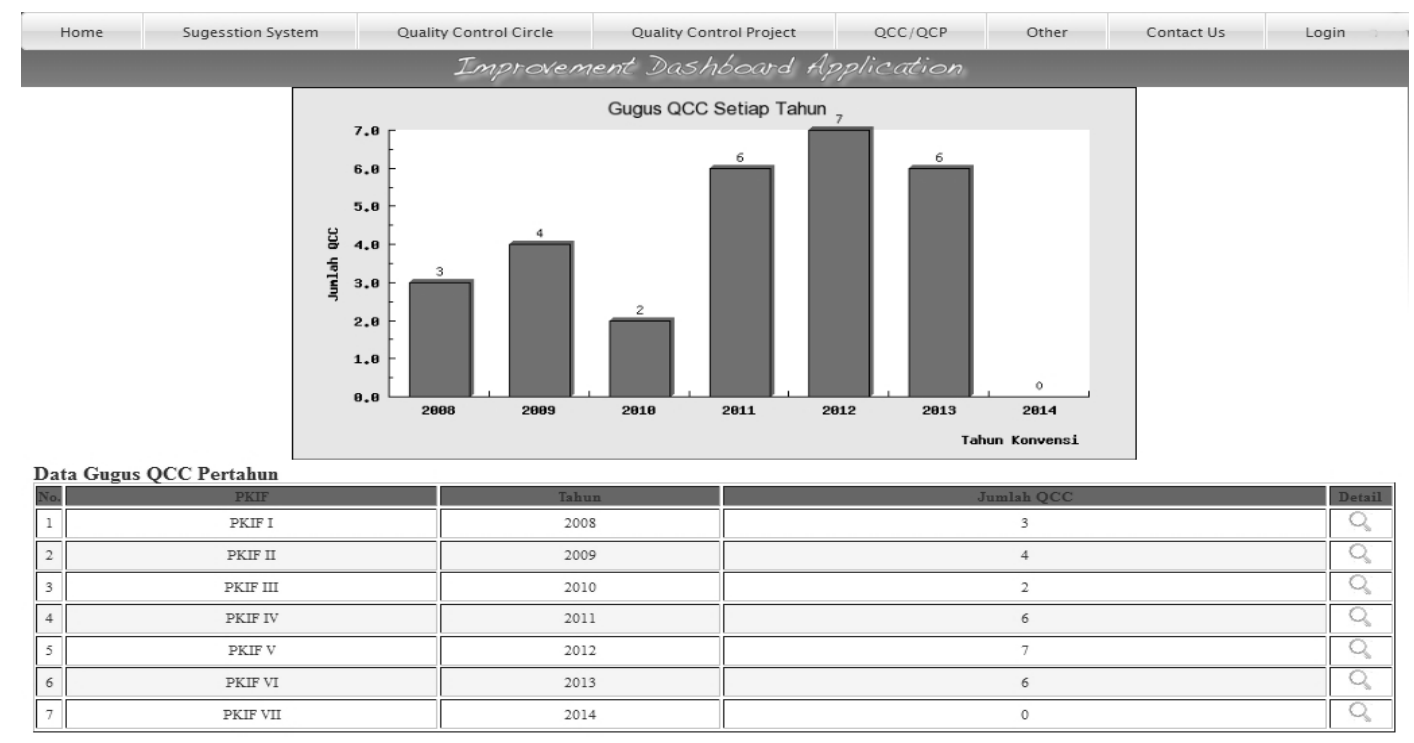

Gambar 16 Halaman grafik QCC

Gambar 17 menampilkan grafik jumlah QCP dan juga tabel keterangan data gugus QCP pertahun. Terdapat juga tombol yang berfungsi untuk melihat data secara detail. 


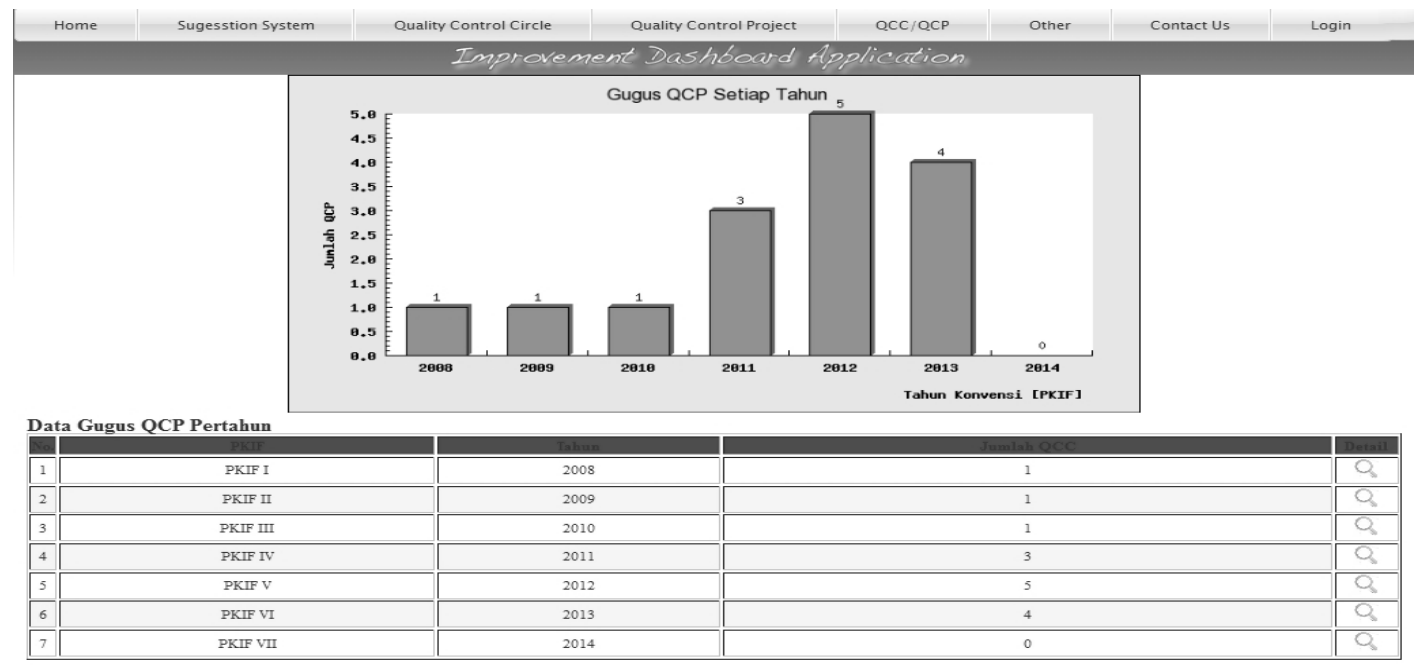

Gambar 17Halaman Grafik QCP

Gambar 18 di bawah ini akan tampil jika memilih sub menu grafik SS Masuk vs SS Diterima yang ada di menu Repor. Jika memilih sub menu grafik SS Plan vs SS Actual yang ada di menu report, maka akan tampil tampilan seperti Gambar 19.

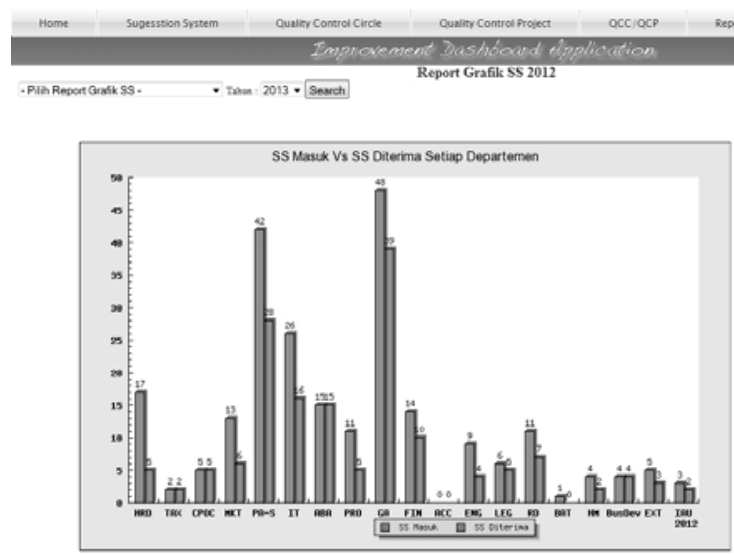

Gambar 18 Halaman Grafik SS Masuk vs SS Diterima
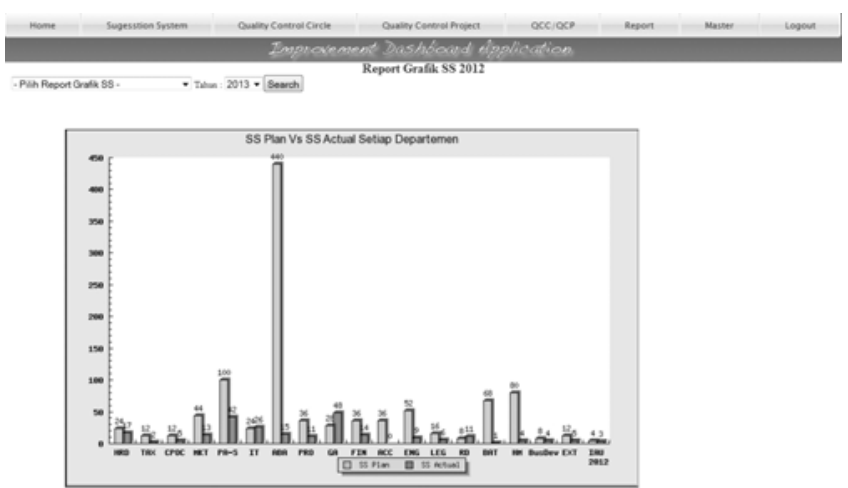

Gambar 19 Halaman Grafik SS Plan vs SS Actual 


\section{PENUTUP}

Berdasarkan hasil analisis, pembahasan, dan evaluasi sistem yang telah diuraikan sebelumnya, simpulan yang dapat diambil adalah sebagai berikut: (1) Penyimpanan data mengenai prosedurprosedur yang sedang berjalan seperti data karyawan, histori jumlah karyawan, data departemen, data devisi, data kategori, pre test/post test, best SS, data SS, data QCC dan QCP sudah terpusat, sehingga dapat digunakan bersama; (2) Rancangan aplikasi database yang telah dibuat mempermudah dalam proses pengumpulan dan pencarian data SS, QCC dan QCP sehingga bagian administrasi tidak merasa kesulitan lagi dalam merekap dan mencari data (seperti pada Gambar 11, dan Gambar 12); (3) rancangan aplikasi database yang telah dibuat sudah menerapkan sistem keamanan berupa authentification dan authorization untuk melindungi data dari pihak-pihak yang tidak berwenang. Untuk menggunakan aplikiasi ini pun user harus melalui proses login terlebih dahulu sehingga hanya user yang diizinkan saja yang bisa menggunakan aplikasi ini; (4) rancangan aplikasi database yang telah dibuat dapat membantu mengurangi waktu yang diperlukan untuk menyelesaikan suatu tugas karena aplikasi yang dibuat sudah dilengkapi dengan fasilitas search dan sort sehingga user tidak perlu melakukan proses pencarian data dengan membuka file satu per satu; (5) rancangan aplikasi yang telah dibuat dapat menampilkan grafik, seperti grafik SS Terkumpul vs SS Diterima, Gugus QCC, Gugus QCP, SS Plan vs Actual dan QCC vs QCP, sehingga user bisa melihat jumlah data pertahun di dalam grafik tanpa harus menghitung satu per satu datanya (seperti Gambar 16 - Gambar 19).

\section{DAFTAR PUSTAKA}

Connoly, Thomas and Begg, Carolyn. (2010); Database System. A Practical Approach to Design Implementation, and Management ( $5^{\text {th }}$ ed.). Boston: Addison Walley.

Gaikwad, Vishal V. dan Gaikwad, Anita V. (2009). Quality Circle as an Effective Management Tool: A Case Study of Indira College of Engineering and Management Library. International Conference on Academic Libraries (ICAL-2009). Diakses 17 Mei 2013 dari http://crl.du.ac.in/ical09/papers/index_files/ical-111_76_183_2_RV.pdf.

Prasanna, N.K.K. dan Desai, Tushar N. (2011). Quality circle implementation for maintenance management in petrochemical industry. Journal of Engineering Research and Studies, 9767916. Diakses $17 \quad 2013$ mei dari http://www.technicaljournalsonline.com/jers/VOL\%20II/JERS\%20VOL\%20II\%20ISSUE\%2 0II\%20APRIL\%20JUNE\%202011/ARTICLE\%2029\%20JERS\%20VOL\%20II\%20ISSUE\%2 0II\%20APRIL-\%20JUNE\%202011.pdf. 